\title{
Importance of Technology Acceptance Assessment for Successful Implementation and Development of New Technologies
}

\author{
Hamed Taherdoost $\mathbf{t}^{1,2,3,4,5^{*}}$ \\ ${ }^{1}$ Hamta Group, Hamta Business Solution Sdn Bhd, Malaysia \\ ${ }^{2}$ Ahoora Ltd, Management Consultation Group, Malaysia \\ ${ }^{3}$ Research Club, Research and Development Group, Malaysia \\ ${ }^{4}$ Hamta Academy, Advanced Academic and Industrial Training Centre, Malaysia \\ ${ }^{5}$ Tablokar Co, Switchgear Panel Manufacturer, Iran
}

*Corresponding author: Hamed Taherdoost, Hamta Group, Kuala Lumpur, Malaysia.

Received Date: December 19, 2018

Published Date: January 08, 2019

\section{Introduction}

It is significant to note that user acceptance and confidence are crucial for further development of any new technology $[1,2]$. Businesses have facilitated or planning to facilitate their business platform to increase personnel efficiency, marketing improvement, cost reduction and increase profitability. Therefore, recognition the needs and acceptance of individuals is the beginning stage of any businesses and this understanding would be helpful to find the way of future development [3-5].

In general, acceptance is defined as "an antagonism to the term refusal and means the positive decision to use an innovation" [6-8]. Decision makers need to know the issues that influence on users' decision to use a particular system, so they would be able to take them into account during the development phase [7,8]. Several researches developed theories and models to describe and analyze user acceptance and each of these models determines different factors to explain user acceptance [9]. The question about user acceptance is related to all researchers who want to presage which technologies will prove appropriate for an organization $[9,10]$.

On the other point of view, user acceptance is very important to the successful implementation of any new technology [11]. Additionally, it is significant to note that technology's features play a vital role in determining whether individuals involved in an activity will use it or not [23]. Thus, understanding the users' perception towards adoption of new technology could help facilitate further growth of the implementation of that particular technology $[12,13]$.
Thus, academicians and practitioners are interested to realize the factors that drive users' acceptance or rejection of new information technologies [14]. Answering this question may help them to better methods for designing, evaluating and predicting the response of the users to the new technologies [15]. Technology acceptance models and theories have been applied in a wide variety of domains to understand and to predict users' behavior such as voting, dieting, family planning, donating blood, women's occupational orientations, breast cancer examination, choice of transport mode, turnover, using birth control pills, education, consumer's purchase behaviors, and computer usage [16-18]. Several researched in the field of technology acceptance, developed frameworks and models to assess the usage of new technologies and these models introduce factors that can affect the user acceptance such as Theory of Reasoned Action (TRA) [19], Theory of Interpersonal Behaviour (TIB) [20], Social Cognitive Theory (SCT) [21-24], Theory of Planned Behavior (TPB) [25], Diffusion of Innovation Theory (DIT) [26], Technology Acceptance Model (TAM) [27-29], Extension of TAM [30,31], Motivational Model (MM) [32], Uses and Gratification Theory (UGT), Model of PC Utilization (MPCU) [33], Igbaria's Model [34], Unified Theory of Acceptance and Use of Technology (UTAUT) [35], Compatibility UTAUT (C-UTAUT) [36], Perceived Characteristics of Innovating Theory (PCIT) [37] and E-Service Technology Acceptance Model (ESAM) [4] and many studies have used these traditional frameworks to conduct their researches and the rest combined previous models or add new constructs to developed models to carry out their study. 
In fact, a great technology and application might be designed and developed but if people do not get involve and do not use it, the project is failed, thus, user acceptance is an undeniable key of any further implementation and development of any technology and application. In other words, in order to increase the level of technology usage and user adoption, the emphasis on factors that can influence on user acceptance should be raised. Recognition the needs and acceptance of individuals is the beginning stage of any businesses and this understanding would be helpful to find the way of future development, thus academicians and practitioners are interested to realize the factors that drive users' acceptance or rejection of new technologies.

\section{Acknowledgement}

None.

\section{Conflict of Interest}

No Conflict of Interest.

\section{References}

1. Taherdoost H, Sahibuddin S, N Jalaliyoon (2013) E-Services Usage Evaluation; Applications' level of Co-Creation and Digitalization. International Journal of Academic Research in Management 2(1): 10-18.

2. Taherdoost H, S Sahibuddin, N Jalaliyoon (2014) Evaluation of Security Factors Effecting on Web-Based Service Adoption. Recent Advances in Telecommunications. Informatics and Educational Technologies, pp. 117-123.

3. Taherdoost H (2017) Appraising the Smart Card Technology Adoption; Case of Application in University Environment. Procedia Engineering 181: 1049-1057.

4. Taherdoost $H$ (2018) Development of an adoption model to assess user acceptance of e-service technology: E-Service Technology Acceptance Model. Behaviour \& Information Technology 37(2): 173-197.

5. Taherdoost H (2018) A Review of Technology Acceptance and Adoption Models and Theories. Procedia Manufacturing 22: 960-967.

6. Simon B (2001) Wissensmedien im Bildungssektor. Eine Akzeptanzuntersuchung an Hochschulen (Knowledge media in the education system: acceptance research in universities). WU Vienna University of Economics and Business: Wien, Austria. pp. 179.

7. Mathieson K (1991) Predicting user intentions: comparing the technology acceptance model with the theory of planned behavior Information Systems Research 2(3): 173-191.

8. Taherdoost H, Shamsul Sahibuddin, Meysam Namayandeh, Neda Jalaliyoon, Alaeddin Kalantari, et al. (2012) Smart Card Adoption Model: Social and Ethical Perspectives. International Journal of Research and Reviews in Computer Science 3(4): 1792-1796.

9. Taherdoost H, Neda Jalaliyoon, Meysam Namayandeh, Arash Forghani, Mazdak Zamani (2010) Adoption Framework Expansion based on the Computer Ethics' Related Research Models and Ethical Scenarios Analysis. in International Conference on Economics, Business and Management. Manila, Philippines 2: 219-223.

10. Taherdoost H, S Sahibuddin (2015) How Security Issues Can Influence on Usage of Electronic Services. Advances in Information Science and Computer Engineering, pp. 310-316.

11. Taherdoost H, S Sahibuddin, N Jalaliyoon (2012) Smart Card Technology; Awareness and Satisfaction. Journal of Computing 4(6): 128-132.

12. Taherdoost H (2017) Understanding of E-service Security Dimensions and its effect on Quality and Intention to Use. Information and Computer Security 25(5): 535-559.

13. Taherdoost H, M Zamani, M Namayandeh (2009) Study of Smart Card Technology and Probe User Awareness about It: A Case Study of
Middle Eastern Students. in International Conference on Management Technology and Applications. Beijing, China: IEEE.

14. Taherdoost H, M Masrom (2009) An Examination of Smart Card Technology Acceptance Using Adoption Model. in ITI 2009 31st Int. Conf. on Information Technology Interfaces. Cavtat, Croatia, pp. 329-334.

15. Dillon A, M Morris (1996) User Acceptance of Information Technology: Theories and Models. In: M. Williams (ed.) Annual Review of Information Science and Technology, Medford NJ: Information Today 31: 3-32.

16. Taherdoost H, M Masrom, Z Ismail (2009) Adoption model to assess the user acceptance of smart card technology. Journal of US-China Public Administration 6(3): 47-58.

17. Taherdoost H, M Namayandeh, M Masrom (2009) Development a Smart Card Acceptance Model from Ethical Perspective. in International Conference on Frontiers in Education: Computer Science \& Computer Engineering, WorldComp, FECS 2009. Las Vegas, Nevada, USA, 235-239.

18. Taherdoost H, Sahibuddin S, JalaliyoonN (2011) Smart Card Security; Technology and Adoption. International Journal of Security 5(2): 74-84.

19. Fishbein M, I Ajzen (1975) Belief, attitude, intention and behavior: An introduction to theory and research. 1975, MA: Addison-Wesley, pp. 578.

20. Triandis HC (1977) Interpersonal Behavior. Monterey, CA.: Brooks/Cole, pp. 329.

21. Bandura A (1977) Self-efficacy: towards a unifying theory of behavioural change. Psychological Review 84(2): 191-215.

22. Bandura A (1978) Relections on self-efficacy, in Advances in Behavioral research and Therapy. In: Rashman S (Ed) Pergamon Press: Oxford, UK, pp. 237-269.

23. Bandura A (1982) Self-efficacy mechanism in human agency. American Psychologist 37(2): 122-147.

24. Bandura A (1986) Social Foundations of Thought and Action: A Social Cognitive Theory. Englewood Cliffs, USA, pp. 544.

25. Ajzen I (1985) From intentions to actions: A theory of planned behavior. In Kuhl J, Beckmann J(eds). Action Control: From Cognition to Behavior. Springer-Verlag, New York, pp. 3: 11-39.

26. Rogers EM (2003) Diffusion of innovations. $5^{\text {th }}$ edn. New York: Free Press, pp. 512.

27. Davis FD (1986) Technology Acceptance Model for Empirically Testing New End-User Information Systems: Theory and Results, in MIT Sloan School of Management. Cambridge: MA.

28. Davis FD (1989) Perceived usefulness, perceived ease of use and user acceptance of information technology. MIS Quarterly 13(3): 319-340.

29. Davis FD, RP Bagozzi, PR Warshaw (1989) User Acceptance of Computer Technology: A Comparison of two Theoretical models. Management Science 35(8): 982-1003.

30. Venkatesh V, FD Davis (2000) A theoretical extension of the technology acceptance model: four longitudinal field studies. Management Science 46(2): 186-204.

31. Venkatesh V (2000) Determinants of perceived ease of use: Integrating control, intrinsic motivation, and emotion into the technology acceptance model. Information Systems Research 11(4): 342-365.

32. Davis FD, RP Bagozzi, PR Warshaw (1992) Extrinsic and intrinsic motivation to use computers in the workplace. Journal of Applied Social Psychology 22: 1111-1132.

33. Thompson RL, CA Higgins, JM Howell (1991) Personal computing: Toward a conceptual model of utilization. MIS Quarterly 15(1):124-143.

34. Igbaria M, SJ Schiffman, TJ Wieckowski (1994) The respective roles of perceived usefulness and perceived fun in the acceptance of microcomputer technology. Behaviour and Information Technology 13(6): 349-361.

35. Venkatesh V, Michael G. Morris, Gordon B Davis, Fred D Davis (2003) User acceptance of information technology: Towards a unified view. MIS Quarterly 27(3): 425-478. 
36. Bouten MPLM (2008) Compatibility and Technology Acceptance: Consolidating, Validating and Extending Concep, in Faculty of Economics and Business Administration. Maastricht University: Maastricht.
37. Moore GC, I Benbasat (1991) Development of an instrument to measure the perceptions of adopting an informat ion technology innovation. Information Systems Research 2(3): 192-222. 